\title{
RELASI ANTARA KEMAMPUAN PEMECAHAN MASALAH MATEMATIK DAN KEAKTIFAN BELAJAR MATEMATIK SISWA SMP YANG MENGGUNAKAN PENDEKATAN REALISTIC MATHEMATIC EDUCATION BERBANTUAN GEOGEBRA
}

\author{
Citra Megiana-Pertiwi ${ }^{1}$, Tiya Fitriani $^{2}$, Muhammad Afrilianto ${ }^{3}$ \\ 1,2,3 IKIP Siliwangi, Cimahi \\ ${ }^{1}$ citra.megianapertiwi@gmail.com, ${ }^{2}$ tyafiriani38@gmail.com, ${ }^{3}$ \\ muhammadafrilianto01@ikipsiliwangi.ac.id
}

\begin{abstract}
Background of the research is based on the students' low ability of mathematical problem solving and mathematical learning activeness. The purpose of this research is find the relation between students' mathematical problem solving ability and students' mathematical learning activeness by using Realistic Mathematic Education approach using geogebra. The method in this research is the experimental research in the form of pre-test-post-test Control Group Design. In addition, the population for this research is the entire Public middle schools (SMP Negeri) in West Bandung regency. From all public middle schools in West Bandung, a school named SMP Negeri 3 Batujajar is randomly selected, and two classes of the $1^{\text {st }}$ grade students of the school are selected as the research sampling data. The first class becomes an experimental class which gains learning using geogebra assisted realistic mathematic educational approach and the other class gets common learning. The result of the research shows that there is a more positive relation between mathematical problem solving ability and mathematical learning activeness of learning by using Realistic Mathematic Education approach with geogebra rather than using common learning. In addition, the approach gives positive impacts, such as more interactive learning, understanding concepts and more meaningful learning.
\end{abstract}

Keywords: Mathematical Problem Solving Abilities, Mathematical Learning Activeness, Realistic Mathematic Education Approach, Geogebra

\begin{abstract}
Abstrak
Penelitian ini dilakukan karena dilatarbelakangi oleh tingkat Kemampuan Pemecahan Masalah (KPM) matematik yang masih rendah dan keaktifan belajar siswa. Tujuan penelitian ini yakni untuk mengetahui relasi antara KPM matematik dan keaktifan belajar siswa yang menggunakan pendekatan Realistic Mathematic Education (RME) berbantuan geogebra. Metode dalam penelitian ini menggunakan penelitian eksperimen dengan bentuk pre-test-post-test Control Group Design. Populasi dari penelitian ini adalah seluruh siswa SMP Negeri di Kabupaten Bandung Barat. Dari seluruh SMP Negeri di Kabupaten Bandung Barat dipilih salah satu sekolah secara acak, dan terpilihlah SMP Negeri 3 Batujajar dengan sampel penelitian adalah kelas VII yang berjumlah dua kelas. Sedangkan sampel pada penelitian ini adalah kelas VII yang dipilih dua kelas secara acak. Kelas pertama menjadi kelas eksperimen yang memperoleh pembelajaran menggunakan pendekatan Realistic Mathematic Education (RME) berbantuan geogebra dan kelas yang lainnya memperoleh pembelajaran biasa. Hasil penelitian memperlihatkan bahwa terdapat relasi positif yang lebih baik antara KPM matematik dan
\end{abstract}


keaktifan belajar siswa yang pembelajarannya menggunakan pendekatan Realistic Mathematic Education berbantuan geogebra daripada yang menggunakan pembelajaran biasa, serta memberikan dampak positif seperti pembelajaran yang lebih interaktif, pembelajaran yang lebih bermakna dan mampu memahami konsep.

How to cite: Pertiwi, C. M., Fitriani, T., \&Afrilianto, M. A. (2018). Relasi antara Kemampuan Pemecahan Masalah Matematik dan Keaktifan Belajar Matematik Siswa SMP yang Menggunakan Pendekatan Realistic Mathematic Education Berbantuan Geogebra. JPMI - Jurnal Pembelajaran Matematika Inovatif, 1 (4), 513-524.

\section{PENDAHULUAN}

Pengajaran matematika selama ini selalu dikaitkan dengan keberadaan rumus-rumus dan konsep secara verbal yang disampaikan secara satu arah dari guru kepada siswa. Sehingga perkembangan kemampuan matematis siswa menjadi stagnan tanpa peningkatan yang signifikan. Perkembangan dan keberhasilan suatu pembelajaran ditinjau dari tingkat ketercapaian tujuan pembelajaran yang diperoleh. Salah satu tujuan pembelajaran matematika yang dikemukakan oleh Kemendikbud (Anisa, 2014) adalah bertujuan agar siswa menyandang KPM yang terdiri atas kemampuan memahami masalah, kemudian merancang model matematika dan menyelesaikannya, serta menafsirkan hasil yang diperoleh. Sumarmo (Fauziah, 2010) memaparkan bahwa pemecahan masalah adalah hal atau sesuatu yang sangat prinsipil sehingga menjadi tujuan umum dalam pembelajaran matematika, bahkan menjadi jantung dari matematika itu sendiri. Hal ini searah dengan pendapat Ruseffendi (Effendi, 2012) yang memaparkan bahwa KPM sangat penting dalam matematika, dan bukan saja bagi mereka yang nantinya akan mendalami matematika, tapi juga bagi siapapun yang akan menerapkannya dalam berbagai bidang dan dalam kehidupan sehari-hari. Kemudian hal ini diperkuat dengan pendapat Hidayat \& Sariningsih (2018) yang menyatakan bahwa dalam pembelajaran matematika pemecahan masalah merupakan inti pembelajaran yang merupakan kemampuan dasar dalam proses pembelajaran.

Namun pentingnya KPM ini tidak sesuai dengan kenyataan di lapangan yang menunjukan masih rendahnya KPM siswa. Berdasarkan hasil penelitian Sumarmo (Anisa, 2014), ditemukan bahwa KPM siswa sekolah menengah atas (SMA) ataupun siswa sekolah menengah pertama (SMP) tergolong masih rendah. Hal ini akan berdampak buruk dalam jangka panjang karena siswa tidak mempunyai kemampuan guna mengatasi situasi yang belum dikenalnya berdasarkan pengetahuan yang telah dimiliki (Wahyu, 2014). Kemudian untuk mencapai tujuan pembelajaran matematik dipengaruhi juga beberapa faktor, salah satunya adalah keaktifan belajar siswa. Selain untuk meningkatkan pemahaman siswa atas pembelajaran yang diberikan, keaktifan belajar yang baik selaku salah satu cara evaluasi bagi guru mengenai tingkat pemahaman siswa. Hal ini sejalan dengan Wibowo (2016) yang menyatakan bahwa partisipasi aktif siswa sangat berpengaruh pada proses perkembangan berpikir, emosi, dan sosial. Sehingga pendalaman pemecahan masalah yang membutuhkan daya pikir dan daya emosi yang mumpuni dapat teratasi dengan keaktifan siswa ini.

Untuk itu diperlukan sebuah metode pembelajaran yang menjebatani KPM dan keaktifan belajar siswa serta mampu menganalisis tingkat korelasi antara keduanya dengan akurat. Untuk itu pendekatan Realistic Mathematic Education (RME) merupakan metode pembelajaran yang dirasa tepat karena berorientasi pada pembelajaran kontekstual dimana hal 
tersebut sangat diperlukan untuk mengambangkan tingkat belajar siswa. Pendekatan RME ini merupakan pendekatan yang mengajarkan siswa untuk mengkaitkan pembelajaran secara nyata atau ilmiah tidak mengada-ada sehingga akan memudahkan siswa dalam meningkatkan KPM secara mandiri.

Selain itu, untuk memaksimalkan hasil yang didapat, pembelajaran RME dapat dilengkapi dengan sebuah aplikasi penunjang, salah satunya adalah geogebra. Dalam perihal ini geogebra digunakan selaku alat atau media pembelajaran serta alat bantu matematika untuk memberikan paparan atau memvisualisasikan konsep-konsep matematik. Dengan begitu konsep pemecahan masalah dalam matematika dapat lebih mudah dipahami oleh siswa. Kemampuan pemecahan masalah menjadi salah satu destinasi pembelajaran matematika yang harus dicapai oleh siswa. BNSP (Suprika, 2014) memaparkan bahwa pemecahan masalah merupakan salah satu kompetensi strategik yang ditujukkan kepada siswa untuk memahami, memilih pendekatan dan strategi pemecahan, dan menyelesaikan model untuk menyelesaikan masalah. Sehingga permasalahan yang telah disebutkan dapat diselesaikan siswa melalui strategi yang telah dirancang dan lebih lanjut lagi, siswa dapat menemukan tambahan pengetahuan dari proses tersebut.

Dalam proses pemecahan masalah, siswa akan mengalami beberapa langkah atau tahapan yang harus dilalui. Langkah-langkah atau tahapan tersebut salah satunya dipaparkan oleh Polya (Hadi \& Radiyatul, 2014), yaitu: 1) memahami masalah; 2) menentukan rencana strategi pemecahan masalah; (3) menyelesaikan strategi dalam penyelesaian masalah; (4) melakukan pemeriksaan kembali atas jawaban yang diperoleh. Setelah semua langkah ini telah dilalui, maka hasil dari proses pemecahan masalah dapat dilihat dan diukur. Kemudian Hidayat \& Sariningsih (2018) menyatakan pemecahan masalah memuat empat langkah penyelesaiannya yaitu memahami, merencanakan, menyelesaikan masalah sesuai rencana dan melakukan pengecekan kembali terhadap semua langkah yang dikerjakan.

Pengukuran terhadap tingkat KPM siswa perlu dilakukan untuk mengetahui kedalaman kemampuan siswa dalam mengatasi permasalahan baru yang akan dihadapi. Menurut NCTM (Khasanah, 2016), terdapat beberapa indikator untuk mengukur atau menilai KPM matematika siswa, yaitu: 1) siswa dapat mengidentifikasi dan menanyakan unsur-unsur yang diketahui, serta kecukupan unsur yang diperlukan; 2) siswa mampu merumuskan masalah matematik atau menyusun pemodelan matematik yang diperlukan; 3) siswa mampu menerapkan strategi sendiri untuk menyelesaikan beragam masalah atau kasus (baik sejenis maupun masalah baru) terkait matematika maupun diluar matematika; 4) Siswa mampu menjelaskan hasil pemecahan sesuai permasalahan yang diberikan; 5) Siswa dapat menggunakan matematika selaku hal yang bermakna.

Keaktifan belajar tidak bisa dipisahkan dari hasil belajar siswa. Menurut Rousseeau Rahmawati (2012) keaktifan belajar bermakna segala pengetahuan siswa yang diperoleh melalui pengamatan dan bekerja sendiri, melalui fasilitas yang diciptakan sendiri baik secara teknis maupun rohani. Hal ini serupa dengan pandangan Sadirman (Wibowo, 2016) yang menyatakan bahwa keaktifan adalah kegiatan yang bersifat fisik maupun mental, yaitu berbuat dan berpikir sebagai suatu untaian yang tidak dapat dipisahkan. Dari pemaparan ini dapat dipahami bahwa keaktifan siswa tidak hanya berupa fisik, tapi lebih dalam lagi yaitu kepada kesiapan mental dan rohani siswa untuk mendapatkan kesadaran bahwa sebuah pemahaman harus dikonstruksi melalui interaksi. 
Kemudian lebih luas lagi Borneo \& Rabiman (2015) memaparkan bahwa keaktifan belajar ditandai oleh adanya keterlibatan intelektual, emosi, dan fisik secara optimal. Apabila komponen pembangun keaktifan siswa ini telah tersinergi dengan baik, maka dampak dari keaktifan itu sendiri akan meningkat dengan sendirinya dimana akan menjadikan pembelajaran sesuai dengan perencanaan yang telah disusun, serta terjadinya interaksi positif baik antara siswa dan guru, maupun siswa dengan siswa lainnya. Kondisi ini sesuai dengan indikator keaktifan menurut Mardiyan (2012) yaitu siswa antusias ketika mengikuti pembelajaran, menjawab pertanyaan dan mengerjakan tugas yang diberikan, serta berani memaparkan hasil aktivitasnya di kelas. Kemudian menurut Wibowo (2016) terdapat beberapa upaya yang dapat dilakukan guru demi meningkatkan keaktifan belajar siswa dalam pembelajaran, yaitu dengan meningkatkan ketertarikan dan motivasi siswa, serta menggunakan media dalam pembelajaran. Lebih lanjut lagi dalam meningkatkan minat siswa tentunya tidak terkecuali dari metode pembelaran yang diterapkan serta kemampuan guru dalam menyampaikannya. Sehingga dalam hal meningkatkan keaktifan belajar siswa, sangat bergantung pada metode pembelajaran yang digunakan dan kemampuan guru.

Konsep utama dari pendekatan RME adalah kebermaknaan konsep matematika dalam pembelajaran. Lebih lanjut lagi CORD (Sulastri, Marwan, \& Duskri, 2017) memaparkan bahwa suatu pengetahuan akan menjadi bermakna jika proses pembelajaran siswa dilaksanakan dalam suatu situasi maupun pembelajaran yang menggunakan permasalahan realistik. Sehingga pada dasarnya pembelajaran RME merupakan pembelajaran yang menggunakan permalasahan realistik atau pengalaman sehari-hari siswa sebagai visualisasi dalam mengasosiasikan materi. Hal tertera ini akan memudahkan siswa dalam meningkatkan pemahamannya karena melibatkan berbagai hal yang sudah familiar bagi siswa tersebut. Terkait dengan pendekatan RME, tidak dapat dilepaskan dari prinsip dasar dan karakteristik pembelajaran yang masing-masing membangun konsep RME. Pengembangan prinsip dasar RME salah satunya dikembangkan oleh Gravemeijer (Ningsih, 2014), yaitu: a) GuidedReinvention and Progressive Mathematization (Penemuan terbimbing dan Bermatematika secara Progresif); b) Didactical Phenomenology (fenomena Pembelajaran); c) Self-developed Model (Pengembangan Model Mandiri). Kemudian karakteristik RME dikemukakan oleh Treffers (Wijaya, 2012), yaitu: a) penggunaan konteks; b) penggunaan model untuk proses matematisasi progresif; c) pemanfaatan hasil konstruksi siswa; d) interaktivitas; dan e) keterkaitan.

Prinsip dasar dan karakteristik RME ini membangun konsep kontekstual secara keseluruhan sehingga pembelajaran melalui pendekatan RME dapat dilaksanakan dengan dasar yang kuat. Berdasarkan uraian-uraian tersebut disimpulkan bahwa seseorang akan tekun mempelajari sesuatu jika yang dipelajarinya bermanfaat dan digunakan dalam kehidupannya. Begitupun dengan pembelajaran matematika, siswa akan berminat pada pembelajaran matematika jika yang ia pelajari bermanfaat bagi diri, kehidupan dan masa depannya. Oleh karena itu, perlu pembelajaran matematika yang mengarah dan merujuk pada kehidupan nyata dan pengalaman siswa.

Salah satu aplikasi atau software penunjang pembelajaran matematika adalah software Geogebra. Geogebra merupakan akronim dari "Geometry and Algebra", yaitu sebuah perangkat lunak untuk mengatasi berbagai kesulitan atau soal geometri dan aljabar bagi para pengguna. Geogebra diciptakan dan dikembangkan oleh Markus Hohenwarter. Penggunaan geogebra akan memudahkan dalam memahami materi geometri, aljabar dan kalkulus, karena pada dasarnya perangkat ini digunakan sebagai media pembelajaran. 
Ada banyak fasilitas dan utilitas dalam Geogebra. Mahmudi (Nur, 2016) memaparkan bahwa penggunaan Geogebra memberikan beberapa kemudahan dan keuntungan, yaitu:

1) Lukisan-lukisan dapat dibuat dengan cepat dan lebih akurat dibandingkan dengan membuat secara manual.

2) Terdapat fitur animasi dan dragging yang dapat memberikan gambaran visual lebih jelas kepada siswa terkait konsep matematika yang sedang dipelajari.

3) Dapat digunakan sebagai alat evaluasi atau koreksi untuk mengetahui lukisan yang dibuat sudah benar.

4) Mempermudah proses analisis sifat-sifat yang terkandung pada suatu objek matematika.

\section{METODE}

Penelitian ini meimplikasikan dua kelas sebagai populas, yakni kelas eksperimen beserta kelas kontrol. Semua kelas diberi pretes dan postes. Kelas eksperimen memperoleh pembelajaran matematika dengan pendekatan RME berbantuan geogebra sebagai perlakuan dan kelas kontrol memperoleh pembelajaran seperti biasa. Maka menurutnya metode penelitian ini adalah penelitian eksperimen dalam bentuk pre-test-post-test Control Group Design. Menurut Ruseffendi (2010), desain penelitian digambarkan sebagai berikut:

$$
\begin{array}{llll}
\text { A } & 0 & X & 0 \\
\text { A } & 0 & &
\end{array}
$$

Keterangan:

A : Pengambilan sampel dilakukan secara acak menurut kelas

$0 \quad$ : Pretes $=$ Postes (soal tes KPM matematik dan angket keaktifan belajar)

$\mathrm{X} \quad$ : Pembelajaran dengan pendekatan RME berbantuan geogebra

Instrumen yang digunakan pada penelitian ini ialah berupa instrumen tes dan bukan tes. Instrumen tes berupa tes KPM matematik yang dibuat berdasarkan materi yang terdapat dalam Kurikulum 2013 yaitu bangun datar segiempat dan segitiga yang akan diintegrasi dengan indikator KPM matematik dengan tujuan untuk menaksir KPM matematik siswa. Soal yang diujikan pada pretes dan postes adalah soal yang sama. Instrumen tes yang berbentuk soal uraian sebanyak 6 soal, sedangkan instrumen bukan tes berbentuk angket skala sikap tentang keaktifan belajar matematik sebanyak 20 pernyataan.

\section{HASIL DAN PEMBAHASAN}

\section{Hasil}

Rekapitulasi statistika deskriptif data hasil penelitian secara keseluruhan dapat dilihat dalam bentuk tabel 1.

Tabel 1. Statistika deskripstif hasil tes

\begin{tabular}{|c|c|c|c|c|c|c|}
\hline \multirow{2}{*}{ Kemampuan } & \multirow{2}{*}{ Statistik } & \multicolumn{2}{|c|}{ Kelas Eksperimen } & \multicolumn{2}{|c|}{ Kelas Kontrol } & \multirow{2}{*}{ SMI } \\
\hline & & Pretes & Postes & Pretes & Postes & \\
\hline \multirow{2}{*}{$\begin{array}{c}\text { Pemecahan masalah } \\
\text { matematik }\end{array}$} & $\bar{x}$ & 5,03 & 16,26 & 7,74 & 13,87 & \multirow{2}{*}{24} \\
\hline & $\mathrm{S}$ & 2,520 & 3,782 & 2,457 & 3,206 & \\
\hline \multirow{2}{*}{ Keaktifan belajar } & $\bar{x}$ & 49,21 & 60,87 & 48,90 & 58,82 & \multirow{2}{*}{80} \\
\hline & $\mathrm{S}$ & 5,256 & 11,237 & 5,654 & 5,599 & \\
\hline
\end{tabular}

KPM matematik dan keaktifan belajar siswa 
Deskripsi statistik yang terdapat pada tabel 1. Menunjukkan bahwa terdapat perbedaan anatara kelas eksperimen dan kelas kontrol. Dari Tabel 1 dapat diamati bahwa skor rata-rata pretest kelas eksperimen dan kelas kontrol KPM tidak jauh berbeda. Hal ini mempresentasikan bahwa kemampuan awal kedua kelas tersebut sama, dalam hal ini samasama belum mengetahui mengenai materi segitiga dan segiempat. Sedangkan skor rata-rata posttest kedua kelas tersebut berbeda cukup jauh untuk KPM matematik dan keaktifan belajar matematik. Hal ini menunjukkan bahwa KPM matematik maupun keaktifan belajar siswa kelas eksperimen lebih baik daripada kelas kontrol. Akan tetapi untuk melihat perbedaan tersebut signifikan atau tidak maka dilakukan uji statistik.

\section{Analisis Kemampuan Pemecahan Masalah Matematik dan Keaktifan Belajar Siswa Kelas Eksperimen}

a. Uji Normalitas Kelas Eksperimen

Uji normalitas skor postes kelas eksperimen dihitung menggunakan software SPSS 23 menggunakan uji Kolmogorov-Smirnov. Kriteria pengujiannya adalah jika nilai sig. $\geq 0,05$ maka data berdistribusi normal. Jika sig. $<0,05$ maka data tidak berdistribusi normal. Hasil yang diperoleh terdapat pada Tabel 2.

Tabel 2. Uji Normalitas Postes KPM dan Keakatifan Belajar Kelas Eksperimen

\begin{tabular}{ccccccc}
\hline Kemampuan & $\mathbf{N}$ & $\overline{\boldsymbol{x}}$ & $\mathbf{S}$ & Statistic & Sig. & Interpretasi \\
\hline $\begin{array}{c}\text { Pemecahan masalah } \\
\text { matematik }\end{array}$ & 39 & 16,26 & 3,782 & 0,117 & 0,193 & Normal \\
$\begin{array}{c}\text { Keaktifan Belajar } \\
\text { Katidak }\end{array}$ & 39 & 60,87 & 11,237 & 0,143 & 0,044 & $\begin{array}{c}\text { Tidak } \\
\text { Normal }\end{array}$ \\
\hline
\end{tabular}

Berdasarkan Tabel 2 tampak bahwa pada kelas ekperimen untuk kemempuan pemecahan masalah matematik memiliki nilai sig. 0,193 sehingga sesuai dengan kriteria pengujian maka KPM berdistribusi normal. Sedangkan untuk kemampuan keaktifan belajar memiliki sig. 0,044 sesuai dengan kriteria pengujian data tidak berdistribusi normal. Karena salah satu data tidak berdistribusi normal maka untuk melihat seberapa kuat relasi antara kedua kemampuan tersebut dilakukan uji korelasi spearman dengan taraf signifikansi 0,05.

\section{b. Uji Korelasi Kelas Eksperimen}

Hipotesis yang akan diuji:

Ho: tidak terdapat relasi yang positif antara KPM matematik dan keaktifan belajar siswa kelas Eksperimen

Ha: terdapat relasi yang positif antara KPM matematik dan keaktifan belajar siswa kelas Eksperimen

Kriteria pengujiannya adalah jika nilai sig.(2-tailed) $>0,05$ maka Ho diterima. Hasil uji korelasi dengan menggunakan software SPSS 23 terdapat pada tabel 3.

Tabel 3. Uji korelasi data postes KPM dan keaktifan belajar siswa kelas Eksperimen

\begin{tabular}{cccc}
\hline Instrumen & N & Spearman Correlation & Sig.(2-tailed) \\
\hline $\begin{array}{c}\text { Kemampuan pemecahan } \\
\text { masalah matematik }\end{array}$ & 39 & 1.000 & \\
Angket keaktifan belajar & 39 & 0,615 & 0,000 \\
\hline
\end{tabular}


Berdasarkan Tabel 3 sesuai dengan kriteria pengujian maka untuk sampel kelas eksperimen memiliki nilai sig.(2-tailed) sebesar 0,000 (sig.2-tailed <0,05) maka Ho ditolak, dapat disimpulkan terdapat relasi antara KPM matematik dan keaktifan belajar siswa kelas eksperimen.

\section{Analisis Kemampuan Pemecahan Masalah Matematik dan Keaktifan Belajar Siswa Kelas Kontrol}

a. Uji Normalitas Kelas Kontrol

Uji normalitas skor postes kelas kontrol dihitung menggunakan software SPSS 23 menggunakan uji Kolmogorov-Smirnov. Kriteria pengujiannya adalah jika nilai sig. $\geq 0,05$ maka data berdistribusi normal. Jika sig. $<0,05$ maka data tidak berdistribusi normal. Hasil yang diperoleh terdapat pada Tabel 4.

Tabel 4. Hasil Uji Normalitas Data Postes Kemampuan Pemecahan Masalah Matematik dan Keakatifan Belajar Kelas Kontrol

\begin{tabular}{ccccccc}
\hline Kemampuan & $\mathbf{N}$ & $\overline{\boldsymbol{x}}$ & $\mathbf{S}$ & Statistic & Sig. & Interpretasi \\
\hline $\begin{array}{c}\text { Pemecahan masalah } \\
\text { matematik }\end{array}$ & 38 & 13,87 & 3,206 & 0,148 & 0,034 & Tidak \\
Keaktifan Belajar & 38 & 58,82 & 5,599 & 0,088 & 0,200 & Normal \\
\hline
\end{tabular}

Berdasarkan Tabel 4 terlihat bahwa pada kelas kontrol untuk kemempuan pemecahan masalah matematik memiliki nilai sig. 0,034 sehingga sesuai dengan kriteria pengujian maka KPM tidak berdistribusi normal. Sedangkan untuk kemampuan keaktifan belajar memiliki sig. 0,200 sesuai dengan kriteria pengujian data berdistribusi normal. Karena salah satu data tidak berdistribusi normal maka untuk melihat seberapa kuas relasi antara kedua kemampuan tersebut dilakukan uji korelasi spearman dengan taraf signifikansi 0,05.

\section{b. Uji Korelasi Kelas Kontrol}

Hipotesis yang akan diuji:

Ho: tidak terdapat relasi yang positif antara kemampuan pemecahan masalah matematik dengan keaktifan belajar siswa kelas kontrol.

Ha: terdapat relasi yang positif antara kemampuan pemecahan masalah matematik dengan keaktifan belajar siswa kelas kontrol.

Kriteria pengujiannya adalah jika nilai sig.(2-tailed) $>0,05$ maka Ho diterima. Hasil uji korelasi dengan menggunakan software SPSS 23 terdapat pada tabel 3.

Tabel 5. Hasil uji korelasi data posttest kemampuan pemecahan masalah matematik dan keaktifan belajar siswa kelas kontrol

\begin{tabular}{cccc}
\hline Instrumen & N & Spearman Correlation & Sig.(2-tailed) \\
\hline Kemampuan pemecahan & 30 & 1.000 & \\
masalah matematik & 30 & 0,346 & .034 \\
Angket Keaktifan Belajar & 30 \\
\hline
\end{tabular}

Berdasarkan Tabel 5 sesuai dengan kriteria pengujian maka untuk sampel kelas kontrol memiliki nilai sig.(2-tailed) sebesar 0,034 (sig.2-tailed < 0,05) maka Ho ditolak, dapat disimpulkan terdapat relasi antara yang positif antara KPM matematik dengan keaktifan belajar siswa kelas kontrol. 


\section{Pembahasan}

Berdasarkan hasil penelitian mengenai skor pretes anatar kelas eksperimen dan kelas kontrol, jika dilihat dari nilai rata-rata KPM kedua kelas tersebut tidak terdapat perbedaan yang signifikan. Ditinjau dari skor rata-rata keaktifan belajar siswa antar kedua kelas tersebutpun tidak ada perbedaan yang signifikan. Ini menunjukkan bahwa dari tes awal KPM dan keaktifan belajar siswa memiliki kemampuan awal yang sama. Serta hasil tersebut mempresentasikan bahwa KPM matematik siswa berada pada klasifikasi rendah. Hal tersebut dikarena siswa belum rutin mengerjakan soal-soal kemampuan tingkat tinggi.

Setelah siswa diberikan pretes dan pembelajaran, selanjutnya siswa diberikan postest. Berdasarkan hasil postes nilai rata-rata KPM dan keaktifan belajar siswa baik kelas ekperimen maupun kelas kontrol keduanya meningkat secara signifikan. Rata-rata nilai postes KPM matematik kelas eksperimen dan kontrol memiliki perbedaan rata-rata yang cukup jauh begitupun dengan rata-rata kemampuan keaktifan belajar siswa rata-rata nilai postes kelas eksperimen dan kelas kontrol memiliki rata-rata yang berbeda. Rata-rata kedua kemampuan kelas eksperimen lebih baik dari pada rata-rata kelas kontrol. Hasil rata-rata postes tersebut menunjukkan bahwa KPM matematik siswa SMP Negeri di kabupaten Bandung Barat antar yang pembelajarannya menggunakan pendekatan Realistic Mathematic Education lebih baik daripada yang menggunakan pembelajaran biasa. Hal ini sejalan dengan hasil analisis Muchlis (2012) yang memaparkan siswa yang memperoleh pendekatan PRMI KPMnya lebih baik secara signifikan daripada siswa yang menerima pembelajaran konvensional serta hasil riset Erlina \& Zakaria (2014) memaparkan bahwa setiap tahapan penyelesaian menggunakan geogebra menunjukkan keupayaan yang lebih baik.

Penerapan pembelajaran dengan menggunakan pendekatan RME berbantuan geogebra tidak hanya untuk meningkatkan kemampuan kognitif dan afektif siswa saja. Penelitian ini guna menunjukkan apakah ada relasi atau hubungan yang positif antara KPM dengan keaktifan belajar siswa. Dari hasil riset yang telah dianalisis menunjukkan terdapat relasi yang positif antara KPM matematik dan keaktifan belajar siswa. Koefisien korelasi kelas eksperimen sebebsar 0,615 yang tergolong dalam klasifikasi kuat, artinya jika siswa tesebut memiliki keaktifan belajar yang baik yang baik maka siswa tersebut akan memiliki KPM matematik yang kuat dengan menggunakan pendekatan RME berbantuan geogebra. Menumbuhkan kesukaan siswa dalam memecahkan soal-soal matematika tingkat tinggi dengan sikap antusias dalam belajar, tekun serta memiliki pandangan yang positif. Menelaah dari hasil penelitian kelas kontrol yang memiliki koefisien korelasi sebesar 0,346 tergolong dalam klasifikasi cukup. Ini menunjukkan bahwa siswa yang memiliki keaktifan belajar yang baik maka siswa akan mempunyai KPM yang cukup dengan menggunakan pembelajaran biasa. Hal ini seirama dengan pernyataan Nopiyani, Turmudi, \& Prabawanto (2016) yang menafsirkan bahwa siswa memberikan respon yang positif terhadap pembelajaran matematika realistik yang dibantu oleh geogebra, serta penilitian Fitriani (2015) yang menyimpulkan bahwa siswa yang memperoleh pembelajaran dengan pendekatan Pendidikan Matematika Realistik mapun siswa yang menerima pemebelajaran matematika seperti biasanya sama-sama terdapat hubungan yang positif serta signifikan antara KPM matematik dengan self confidence.

Sejalan dengan pendekatan RME yang memiliki karakteristik untuk melahirkan pembelajaran yang lebih bermakna, sesuai dengan yang dibayangkan siswa serta didukung dengan pemanfaatkan software geogebra tentu menjadikan pembelajaran yang interaktif, keaktifan siswa semasa proses pembelajaran akan meningkat, serta konsep-konsep yang dipelajari akan lebih mudah diterima siswa. Hal ini menunjukkan bahwa siswa yang pembelajarannya 
menggunakan pendekatan RME berbantuan geogebra lebih baik dibandingkan yang menggunakan pembelajaran biasa.

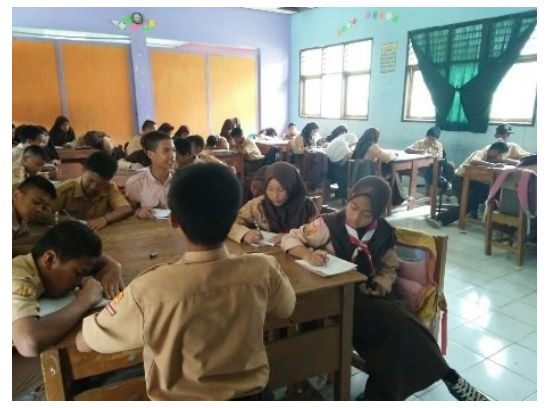

Gambar 1. Kegiatan Belajar Di Kelas Eksperimen

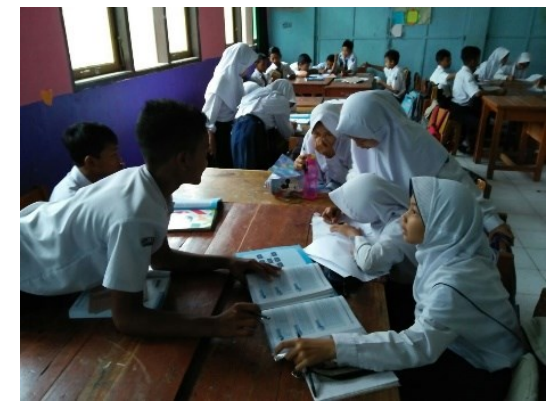

Gambar 2. Kegiatan Belajar Di Kelas Kontrol

\section{KESIMPULAN}

Berdasarkan hasil analisis data dan pembahasan yang telah dipaoarkan, disimpulkan bahwa:

1. Terdapat relasi yang positif anatara KPM matematik dan keaktifan belajar siswa SMP dengan klasifikasi kuat yang menggunakan pendekatan Realistic Mathematic Education berbantuan geogebra.

2. Terdapat relasi yang positif anatara KPM matematik dan keaktifan belajar siswa SMP dengan klasifikasi cukup yang menggunakan pembelajaran biasa.

3. Pembelajaran yang menggunakan pendekatan Realistic Mathematic Education berbantuan geogebra pada siswa SMP lebih baik dari pada pembelajaran biasa

4. Kolaborasi anatara pendekatan Realistic Mathematic Education dengan geogebra dapat meningkatkan kemampuan kognitif dan afektif siswa serta menjadikan pembelajaran yang interaktif, bermakna dan menguasai konsep.

\section{DAFTAR PUSTAKA}

Anisa, W. N. (2014). Peningkatan Kemampuan Pemecahan Masalah dan Komunikasi Matematik Melalui Pembelajaran Pendidikan Matematika Realistik untuk Siswa SMP Negeri di Kabupaten Garut. Jurnal Pendidikan Dan Keguruan, 1(1).

Borneo, D., \& Rabiman. (2015). Penerapan Metode Pembelajaran Inkuiri untuk Meningkatkan Keaktifan Belajar dan Hasil Belajar Mata Diklat Sistem Injeksi Bahan Bakar Bensin Pada Siswa Kelas XII TKR SMK Muhammadiyah Cangkringan Sleman Yogyakarta. Taman Vokasi, 3(1).

Effendi, L. A. (2012). Pembelajaran Matematika dengan Metode Penemuan Terbimbing untuk Meningkatkan Kemampuan Representasi dan Pemecahan Masalah Matematis Siswa SMP. Jurnal Penelitian Pendidikan, 13(2), 1-10.

Erlina, A., \& Zakaria, E. (2014). Kesan penggunaan perisian geogebra ke atas keupayaan penyelesaian masalah dan pencapaian matematik pelajar. Jurnal Pendidikan Matematik, 2(1), 51-64.

Fauziah, A. (2010). Peningkatan Kemampuan Pemahaman dan Pemecahan Masalah Matematik Siswa SMP Melalui Strategi REACT. Forum Kependidikan, 30(1), 1-13. 
Fitriani, N. (2015). Hubungan Antara Kemampuan Pemecahan Masalah Matematis dengan Self Confidence Siswa SMP Yang Menggunakan Pendekatan Pendidikan Matematika Realistik. Jurnal Euclid, 2(2), 341-351.

Hadi, S., \& Radiyatul. (2014). Metode Pemecahan Masalah Menurut Polya untuk Mengembangkan Kemampuan Siswa dalam Pemecahan Masalah Matematis di Sekolah Menengah Pertama. Edu-Mat Jurnal Pendidikan Matematika, 2(1), 53-61.

Hidayat, W., \& Sariningsih, R. (2018). Kemampuan Pemecahan Masalah Matematis dan Adversity Quotient Siswa SMP Melalui Pembelajaran Open Ended. Jurnal Nasional Pendidikan Matematika, 2(1), 109-118.

Khasanah, N. U. (2016). Peningkatan Kemampuan Pemacahan Masalah Matematika Melalui Strategi Realistic Mathematics Education Berbasis Group Investigation. Universitas Muhammadiyah Surakarta.

Mardiyan, R. (2012). Dalam Pembelajaran Akuntansi Materi Jurnal Penyesuaian Pada Siswa Kelas Xi Ips 3 Sma Negeri 3 Bukittinggi Dengan Metode Bermain Peran ( Role Playing ). Jurnal Pakar Pendidikan, 10(2), 151-162.

Muchlis, E. E. (2012). Pengaruh Pendekatan Pendidikan Matematika Realistik Indonesia (PMRI) Terhadap Perkembangan Kemampuan Pemecahan Masalah Siswa Kelas II SD Kartika 1.01 Padang. Jurnal Exacta, X(2), 136-139.

Ningsih, S. (2014). Realistic Mathematics Education: Model Alternatif Pembelajaran Matematika Sekolah. JPM IAIN Antasari, 01(2), 73-94.

Nopiyani, D., Turmudi, \& Prabawanto, S. (2016). Penerapan Pembelajaran Matematika Realistik Berbantuan GeoGebra untuk Meningkatkan Kemampuan Komunikasi Matematis Siswa SMP. Mosharafa: Jurnal Pendidikan Matematika, 5(2), 45-52.

Nur, I. M. (2016). Pemanfaatan Program Geogebra dalam Pembelajaran Matematika, 5(1), $10-19$.

Rahmawati, E. D. (2012). Penerapan Model Pembelajaran Kooperatif Tipe Group Investigation (GI) untuk Meningkatkan Keaktifan Belajar dan Hasil Belajar Mata Pelajaran Sosiologi Pada Siswa Kelas X 3 SMA Negeri Colomadu Tahun Pelajaran 2011/2012. Jurnal Sosialitas, 2(1).

Ruseffendi, E. T. (2010). Dasar-Dasar Penelitian Pendidikan dan Bidang Eksakta Lainnya (Cetak Pert). Bandung: Tarsito.

Sulastri, Marwan, \& Duskri. (2017). Kemampuan Representasi Matematis Siswa SMP Melalui Pendekatan Pendidikan Matematika Realistik. Beta, 10(1), 51-69.

Suprika, G. (2014). Pengaruh Penerapanmodel Pembelajaran Kooperatif Co-op Co-op dengan Strategi Belajar Aktif Index Card Match (ICM) Terhadap Kemampuan Pemecahan Masalah Matematika Siswa SMP Negeri 23 Pekanbaru. UIN SUSKA Riau Pekanbaru. 
Wahyu, H. (2014). The Implementation of MEAs Instruction to Students' Mathematics Problem Solving and Connecting Ability. In Proceeding of International Conference on Research, Implementation and Education of Mathematics and Sciences 2014. Yogyakarta State University.

Wibowo, N. (2016). Upaya Peningkatan Keaktifan Siswa Melalui Pembelajaran Berdasarkan Gaya Belajar Di Smk Negeri 1 Saptosari. Jurnal Electronics, Informatics, and Vocational Education (ELINVO), 1(2), 128-139.

Wijaya, A. (2012). Pendidikan Matematika Realistik, Suatu Alternatif Pendekatan Pembelajaran Matematika (Pertama). Yogyakarta: Graha Ilmu. 
